УДК $81 ' 373.46:[811.111+811.161 .2]$

https://doi.org/10.31548/philolog2021.02.027

\title{
DIACHRONIC ANALYSIS OF THE CONCEPTS CRIME AND PUNISHMENT
}

\author{
V. P. SNITSAR, PhD in Philology, Associate Professor, \\ Borys Grinchenko Kyiv University \\ E-mail: vl.snitsar@gmail.com \\ https://orcid.org/0000-0002-9553-574X
}

\begin{abstract}
The paper addresses the issues of reconstruction of Proto-Indo-European roots and original meanings of the words denominating the concepts CRIME and PUNISHMENT in English and Ukrainian as well as their semantic development over several historical periods. The methodology employed includes the comparative-historical method incorporating etymological analysis, the techniques of external and internal reconstruction, componential and contrastive analyses. The major findings refer to the identification of the primordial senses of the verbalised concepts CRIME and PUNISHMENT that constitute the structure of the collective unconscious of the early Germans and the early Slavs. The reconstructed linguistic data make it possible to conclude that the archetypal meanings "cry of distress", "to sift, to separate" encoded in the inner form of the English noun crime gave rise to the legal meanings "deceit, fraud, treachery", "offence punishable by law". The etymological analysis of the Ukrainian word злочин makes it clear that the specialized legal meaning 'a socially dangerous act' evolved from the original meaning "crooked, bent, curved". The etymological connection of the English word punishment with the Proto-Indo-European root *khoe/oi-'punish, compensate, pay price, avenge' points to the earliest Germanic conceptions of punishment as blood feud, vengeance, compensation for damages or payment for a bride, whereas in Old Slavic tradition, punishment is viewed as a punitive measure intended to cause physical pain or inflict intense humiliation, denigration, or extreme fear to a person.
\end{abstract}

Keywords: concept, reconstruction, inner form, etymological analysis, semantic development, collective unconscious.

Introduction. Linguistic worldview reconstruction is a priority of modern linguistics. The elements that make it possible are increasingly referred to by scientists from different perspectives as "culture constants" [17, p. 54], "ethnic constants" and "diachronic constants" [2, p. 79]. Gukhman considers the latter as being able to model invariant tendencies of language evolution [8, p. 56]. Since all language categories reflect the peculiarities of the conceptual worldview of language speakers, thus it is possible to trace the changes of conceptual dominants in different historical periods by studying the diachronic development of language categories.

Recent research and publications. Language-based reconstruction of material and spiritual culture of ethnic groups is one of the most promising areas of linguistic research. Throughout the last decade, there has been a growing interest in the diachronic studies of concepts $[2 ; 3,11 ; 15$; 17]. Numerous cognitive studies have shown that concept is not static, it evolves over time since the dynamics of conceptual content is triggered by social, historical, cultural factors and ethical principles. The diachronic study of concepts is essential, since it provides a better understanding of the content, structure, mechanisms, ways and time of concept verbalisation, as well as crosscultural differences of its components for different nations. The diachronic analysis of linguistic data makes it possible to reconstruct the earliest IndoEuropean conceptions of various phenomena attested in the historical Indo-European dialects.

The purpose of the research is to reconstruct Proto-Indo-European roots and original meanings of the lexical units denominating the concepts CRIME and PUNISHMENT in English and Ukrainian and trace diachronic variation of the conceptual content.

The methods of the research are the following: the comparative-historical method incorporating etymological analysis, the techniques of external and internal reconstruction used to reconstruct Proto-Indo-European roots and original meanings of the lexical units denominating the concepts CRIME and PUNISHMENT in English and Ukrainian and trace their semantic development; componential analysis that is used to analyse the words through structured sets of semantic features; contrastive analysis that is used to identify isosemic and allosemic features constituting the structure of the concepts CRIME and PUNISHMENT in the contrasted languages over certain historical periods.

Results. The conceptions of good and evil, just and unjust, normal and abnormal are archaic patterns and images derived from the collective unconscious that shape legal culture and legal consciousness. According to Fitzpatrick, "...modern law is inherently mythic and shares origins with the mythology of modernity" [6, p.154]. As noted by Gamkrelidze and Ivanov, the 
principle of binarism permeates the mythological and semantic systems of the ancient IndoEuropean model of the world [7, p. 748]. Major binary oppositions (life-death, heaven-earth, good-bad, right-left) reflect the universal parameters of the world. The understanding of the universe as a hierarchical order is reflected in mythological conceptions. In ancient Greek mythology, the notion of cosmos is opposite to chaos. Mythological cosmos is a cosmos of order and hierarchy, a "lawful" cosmos. Irrational chaos is contrasted with an ordered cosmos. In the context of law, the conceptual distinctions are based on the binary principle of normative versus non-normative, just versus unjust, order versus disorder, crime versus innocence, etc.

As evidenced by the collective and cumulative history of humankind, crime and punishment are the long-standing social phenomena inextricably bound up with each other. In this regard, Melnychuk makes an analogy between primordial evil associated with chaos and punishment as a cosmogonic act aimed at restoring divine order [12, p. 45].

Concepts having significant impact on society within a particular historical period appear to be the most dynamic, two of such sociocultural constants being the concepts CRIME and PUNISHMENT that register the code of human conduct in a particular society. As a concept is characterised by a set of attributes/features, it can be described by revealing the features making up its structure. Concept formation begins with the inner form that is defined as "an etymological feature, a primordial sense of a concept encoded in the outer verbal form" [17, p. 46]. The inner form that is viewed as the fundamental feature underlying the concept retains the aptitude to acquire new meanings over a certain historical period. Thus, the dynamic nature of a concept is evidenced by the fact that its content is constantly enriched with new conceptual characteristics. Exploring the historical (diachronic) component of a concept is of great value for the researcher as etymological data can explain the mechanism of concept formation, metaphorically speaking, "its first steps in the verbal cognitive field of culture" [10, p. 83].

The etymological study of a concept name is an important stage in the understanding of its content. The word denominating the concept receives the status of its name. It conveys the conceptual content in the concentrated form most specifically and precisely. The name of the concept CRIME is the lexeme crime. The English word crime is traditionally reconstructed as PIE "krei- "to sift, separate": Eng. crime < Lat. cernere "to sift, distinguish, separate" < PIE *krei- "to sift, separate" that later gave rise to the legal meanings "deceit, fraud, treachery" > "charge, indictment, accusation" > "offence punishable by law" [13]. The supposed connection of crime with PIE *krei- "to sieve, separate" was rejected by Klein [1]. He suggested (citing Brugmann) that crime may be etymologically connected to PIE *(s)qrei- (enlargement of the imitative base *qer"to shout, cry"), whence also OHG scrian "to cry", MHG schrien, Ger. schreien, ON hreimr "to squeak", hrina "to squeal, squeak" [1, p. 372].

In Old English, the lexeme crime acquired the meanings "sinfulness", "infraction of the laws of God". The meanings "crime", "mortal sin" are attested in the Old French word crimne (12 century). The meaning "any great wickedness or wrongdoing" is from 1510s. The modern legal meaning "offense punishable by law" could have arisen in the late 14th century [13]. Modern dictionary definitions of the lexeme crime and its synonyms offence, wrong, felony contain the semantic components 'offence', 'fault', 'infringement', 'evil', 'injustice', 'deceit', 'illegal or unfair act', and 'violence' that retain the traces of the meanings of crime in the earlier historical periods.

As evidenced by the etymological analysis, the structure of the concept CRIME extended gradually covering several historical periods: the original semantic components: "sifting", "cry"; the meanings attested in the Old English period: "deceit", "fraud", "treason", "accusation"; the meanings attested in the Middle English period: "crime", "mortal sin"; the modern specialized meanings attested in the 14th century: "wrongdoing", "offence punishable by law".

To reconstruct the concept CRIME verbalised in the Ukrainian language, it is necessary to trace the origin of its name - the lexeme злочин (crime). The feature of asymmetry underlies the concept of evil represented by the Ukrainian word зло. The compound злочин consists of the noun зло (evil) and the verb учинити (do, commit). Ukr. зло descends from the Proto-Slavic root " $z$ ๖ $($ (b) "bad, evil, wicked", which can be etymologically linked with the PIE root "ghhuel- "to bend, crook, twist". The meaning of the protofom * $k$ huel is reflected in the meanings of the words derived from it: Skt. hvớratē "he goes a crooked pathway", hvớrati "he runs the wrong way", Avest. zbarəmna- "going around", Lith. ablaut ižviinnas "slantwise, slant, skew", atžúlas "rough, impolite", Latv. zvelu "to turn aside". The reconstructed PIE root * ghuel can be typologically compared to the protoforms reconstructed for the Slavic languages. Thus, for example, the Proto-Slavic root *krivb "curved, bent" gave rise to the numerous derivatives meaning "injustice": OSlav. кривина "injustice, abnormality", кривьда "falsehood, injustice", кривьць "culprit, defendant", Serb.-Cr. крив "guilty", кривац "offender"; крив закон "unfair law", криводел "criminal", кривња "guit". In the lexemes above, we can observe a semantic shift from the original meaning "crooked", bent, twisted" to the specialized legal meanings. The phrase зло оучинити with the meaning "to cause harm" is used from $14-15 \mathrm{c}$. The 
lexeme зълодъъ derived from Proto-Slavic *zъlodějь with the meanings "criminal", "thief", "ill-wisher" is attested in 15 c. [5, p. 266].

The modern dictionary definitions of the lexeme злочин and its synonyms злодіяння (evil deed), злочинство (misdoing), правопорушення (offence, wrongdoing), лиходіŭство (evil-doing) contain the semantic components 'evil', 'wicked act', 'criminal, 'to cause, 'harm' that retain the traces of the meanings of злочин (crime) attested in the earlier historical periods.

As evidenced by the contrastive analysis, the original meanings of the lexical means representing the concept CRIME in English and Ukrainian have been proven dissimilar. The primordial sense "cry of distress" as a natural reaction to grief and pain, which is linked to the concept of crime, is embedded within the lingual consciousness of the early Germans. According to other etymological sources, crime may be etymologically connected to PIE *krei- "to sieve, separate". The Ukrainian word злочин reflects the ancient Slavic conceptions of evil as something crooked, bent, curved (Ukrl. зло < OSI. " Zъlъ(jь) "unkind, evil" < PIE *ĝhuel- "crooked, bent").

The diachronic component of the concept CRIME verbalised in English and Ukrainian contains the common conceptual feature 'violation of ethical principles' (English sinfulness, infraction of the laws of Godl Ukrainian zpix (sin)). The divergent conceptual features are the following: 'cry (cry of distress), 'selection' (to sift, to discriminate), 'a deceitful action' (deceit, fraud), 'accusation' (charge, accusation), 'a non-normative act ' (crime, fault, offence), which are represented in the English language; and the conceptual features 'asymmetry' (кривий (crooked, curved), похилий (bent)), 'human vices' (недобрий (unkind, bad), злий (evil, wicked), несправедливий (unjust)), 'a negative phenomenon' (нещастя (misfortune), біда (trouble), дещо / все зле (something/everything evil)), which are represented in the Ukrainian language.

To reconstruct the concept PUNISHMENT, it is necessary to trace the origin of its name - the lexeme punishment. The ancient Germanic conceptions of blood feud, vengeance, compensation for damages or payment for a bride are reflected in the meaning of the protoform for punishment and in the meanings of the words derived from it, which are attested in the historical Indo-European dialects. As indicated by the linguistic data, punish is derived from Old Fr. puniss-, extended present participle stem of punir "to punish", from L. punire "punish, correct, chastise"; "take vengeance for; inflict a penalty on, cause pain for some offence", earlier poenire, from poena "penalty, punishment" [13]. The protoform can be reconstructed as *khoe/oi-(na-) "punish, compensate, pay price, avenge" that is attested in all major early dialects: Skt. cáyate "avenges", cetár- "avenger", ápaciti- "retribution", Avest. kāy- "pay, compensate", kaēnā- "redemption"; "punishment, retribution", Hom. Gk. tinō "(I) pay, compensate, punish, avenge", tisis "payment, punishment, vengeance, redemption", poinē' "retribution, vengeance, blood feud, payment for murder", Lith. káina "price, payment" (including bride price), OCS cěna "price, payment" [13].

As Gamkrelidze and Ivanov point out, the Indo-European protolanguage had an undifferentiated legal and ritual concept of payment or compensation. A blood feud was the same kind of compensation - payment for blood as compensation for damages or payment for a bride [7, p. 709]. The principle of retributive justice is reflected in the Anglo-Saxon law codes, in particular, in King Alfred Law Code "...if anyone puts out another's eye, let him give his own for it: tooth for tooth, hand for hand.. " [9]. Similarly, the motif of mirror punishment is echoed in the Old Slavic law codes, in particular, in Rus'ka Pravda (Justice of Rus'), the legal code of Kyivan Rus': "Оубьеть моуж(ь) моужа, то мьстить братоу брата, [...] или братоу чадоу, любо сестриноу с(ы)н(о)ви (If a man kills a man, then a brother may avenge the death of his brother $[\ldots]$, or a brother's son or a sister's son may avenge the death of their uncle)" [14].

The name of the concept PUNISHMENT verbalised in the Ukrainian language is the lexeme покарання. It is a prefixal derivative of the ProtoSlavic noun "kara "punishment, penalty", which apparently originally meant "physical punishment" [5, p. 381]. Some etymologists suggest that the lexeme *kara is a derivative of *karati "to scold, to punish", Cz. kárati "to reproach, to scold, (arch.) to punish"; SCr. kárati "to scold, to punish"; others reject this connection suggesting that the verb *karati is formed from the Proto-Slavic noun *kara with suffixes a-ti-. Proto-Slavic ${ }^{*}$ karati is presumably connected with Proto-Slavic *koriti "to scold, to reprimand, to criticise" (the long root vowel is of Proto-Slavic origin) [4, p. 221], as reflected in the meanings of the Old Slavic descendants: OSlav корити "to disgrace" [16, р. 291]; оукарати "to defame, to discredit" [16, p. 292]; покорити "to subdue" [16, p. 292]. ProtoSlavic "koriti is cognate with Latv karinat "tease, irritate", Gk. kápvn" damage, penalty, retribution", L. carino 'I mock smb, bring discredit on smb", Old Irish caire "reproach", deriving from PIE *kar- "to abuse, to blame, to defame, to dishonour", which is linked with *(s)kerr" kor- "to scratch, to cut, to carve, to shear", "to insult, to treat with insolence, indignity, or contempt" [5, p. 381]; Skt. krntáiti "cuts", Avest. kørøntaiti "cuts, flays, cleans (slaughtered animal) ", Hom. Gk. kelro " (I) cut, shear", OHG sceran, OE scieran "shear, cut", Engl. shear [4, p. 221].

The comparative analysis of the reconstructed linguistic data makes it possible to conclude that the original meanings of the protoform for punishment reflect the earliest Germanic conceptions of punishment as blood 
feud, vengeance, compensation for damages or payment for a bride, whereas in Old Slavic tradition, punishment is viewed as a punitive measure intended to cause physical pain or inflict intense humiliation, denigration, or extreme fear to a person.

The diachronic component of the concept PUNISHMENT verbalised in English and Ukrainian contains common conceptual features: 'a punitive action' (English to punish, to chastise/ Ukrainian карати (to punish)), 'physical punishment' (English to cause pain for some offence; suffering / Ukrainian мучити (to torment), різати (to cut), здирати (to shear)). 'The divergent conceptual features are the following: 'monetary penalty (penalty, fine; to compensate, to pay price), represented in the English language; and 'verbal abuse' (ображати (to insult), сварити (to scold), принижувати, ставитися зі зневагою (to treat with insolence, indignity, or contempt); ганьбити (to disgrace), represented in the Ukrainian language.

Conclusions and research prospects. Reconstruction of the earlier stages of a language provides insights into the lives of speakers at the various stages of language evolution, their social and cultural practices. Linguistic data of etymological dictionaries and historical texts made it possible to reconstruct ancient Indo-European conceptions about such long-standing social phenomena as crime and punishment. The article highlights the evolutionary transformations of the concepts CRIME and PUNISHMENT verbalized in English and Ukrainian over several historical periods: from Old English to Modern English and from Old Slavic to Modern Ukrainian.

The comparative diachronic analysis of the language means representing the analysed concepts in the contrasted languages shows that the original meanings of the reconstructed

\section{Список використаних джерел}

1. Антипова А. С. Ассоциативная связь концептов «СМЕРТЬ» и «СЛАВА» как диахроническая константа в картине мира англичан. Вестник НГУ. Серия: Лингвистика. 2007. T. 5. Вып. 2. С. 78-82.

2. Бондаренко $€$.В. Еволюція поняття часу в англійській мові та у дискурсі : автореф. дис. на здобуття наук. ступ. д-ра фрілол. наук: 10.02.04. Харків, 2012. 36 с.

3. Етимологічний словник української мови : [у 7 т. ]. / [гол.ред. О. С. Мельничук]. Київ : Наукова думка, 1985. Т. 2. 572 с.

4. Гухман М. М. Историческая типология и проблема диахронических констант. Москва : Наука, 1981. 249 с.

5. Красавский Н.А. Этимологический анализ синонимического ряда "страх" (на материале немецкого языка). Когнитивные protoforms for crime and злочин proved to be dissimilar. The archetypal meanings "cry of distress", "to sift, to separate" are visible in the inner form of English noun crime and its derivatives. The original meanings of the protoform for the Ukrainian word злочин reflect the ancient Slavic conceptions of evil as something crooked, bent, curved. Universal for the Anglo-Saxon and Ukrainian ethnoses is the perception of crime as violation of ethical principles, infraction of the laws of God. Conceptual differences are conditioned by the specific perception of crime based on images, stereotypes deeply ingrained in national consciousness. The original meanings of the protoform for the English word punishment reflect the earliest Germanic conceptions of punishment as blood feud, vengeance, compensation for damages or payment for a bride, whereas the Ukrainian word покарання is linked to the earliest Slavic conceptions of punishment as a punitive measure intended to cause physical pain or verbal abuse. Universal for the Anglo-Saxon and Ukrainian linguacultures is the perception of punishment as a punitive action intended to cause physical pain, which is a form of criminal liability characteristic of the early medieval law. Allomorphic (divergent) parameters of conceptualization of punishment by the representatives of the contrasted linguacultures within certain historical periods refer to the perception of punishment as monetary penalty by the Anglo-Saxon lingual community and the perception of punishment as verbal abuse by the Ukrainian lingual community.

The obtained results may contribute to further research of other socially centric concepts from a diachronic perspective using etymological dictionaries and historical texts.

аспекты языковой категоризации: [сб. науч. трудов]. Рязань : Изд-во РГПУ, 2000. С. 83-90.

6. Мельничук Н. Ю. Дискурс "злочину" та "покарання" у контексті класичної філософрської парадигми. Львів : Львів. держ. ун-т внутр. справ, 2006. 328 с.

7. Руська Правда. Тексти на основі 5 редакцій. Київ [укл. С. Юшков]. Київ : Вид-во УАН, 1935. 194 c. URL: http://litopys.org.ua/yushkov/ yu.htm/

8. Семегин Т. С. Динаміка семантичної структури бінарних концептів ПРЕКРАСНИЙ / ПОТВОРНИЙ в англійській та українській мовах: автореф. дис. ... канд. філол. наук: спец. 10.02.17. Київ, 20 с.

9. Старославянский словарь (по рукописям X-XI веков). под ред. Р. М. Цейтлин, Р. Вечерки, Э. Благовой]. Москва : Русский язык, 1999. 842 с. 
10. Степанов Ю. С. Концепты. Тонкая пленка цивилизации. Москва : Языки славянских культур, 2007. 248 с.

11. A comprehensive etymological dictionary of the English language [Klein, E. (ed.)]. Amsterdam: Elsevier Publishing Company, 1966. 844 p.

12. Etymological Dictionary of the Slavic Inherited Lexicon [Derksen, R. (ed.)]. LeidenBoston: Brill Academic Publishers, 2008. 684 p.

13. Fitzpatrick P. The Mythology of Modern Law. London: Routledge, 2002. 256 p.

14. Gamkrelidze T. V., Ivanov V. V. IndoEuropean and the Indo-Europeans: $A$ Reconstruction and Historical Analysis of a ProtoLanguage and Proto-Culture. Berlin - New York: Mouton de Gruyter, 1995. 1228 p.

15. King Alfred Law Code. URL: http://www.dr-fnlee.org/docs6 /alfred/ alfred.pdf

16. Levitsksy A. Language worldview of Yakima Indians, compared with English and Ukrainians. Lege Artis. Language yesterday, today, tomorrow. The Journal of University of SS Cyril and Methodius in Trnava. Warsaw: De Gruyter Open, 2016. Vol. I (2). P. 80-128.

17. Online etymology dictionary. URL: http: //www.etymonline. com.

\section{References}

1. A comprehensive etymological dictionary of the English language (1966). [Klein, E. (ed.)]. Amsterdam: Elsevier Publishing Company, 844.

2. Antipova, A. (2007). Assotsiativnaya sviaz kontseptov "SMERT" i "SLAVA" kak diakhronicheskaya konstanta $v$ kartine mira anglichan [The associative link between the concepts DEATH and GLORY as a diachronic constant in the Englishmen's worldview]. Vestnik Novosibirskogo gosudarstvennogo universiteta. Seriya lingwistika i mezhkulturnaya kommunikatsyya [Novosibirsk State University Herald. Series: Linguistics and Intercultural Communication]. V. 5. Issue 2. 78-82. [in Russian].

3. Bondarenko, Ye. (2012). Evolutsiya poniattia chasu $\mathrm{v}$ anhliyskiy movi ta $\mathrm{u}$ dyskursi [Evolution of the Notion of Time in the English Language and in Discourse]. Abstract of PhD Thesis. Speciality 10.02.04. Kharkiv, 35. [in Ukrainian].

4. Etymological Dictionary of the Slavic Inherited Lexicon. (2008). Derksen, R. (ed.). Leiden-Boston: Brill Academic Publishers, 684.

5. Etymolohichnyi slovnyk ukrayinskyoyi movy: [u 7 t. ] (1985) hol. red. O. S. Melnychuk [Etymological dictionary of the Ukrainian language [7 Vols.]. Melnychuk, O. (ed.)]. Kyiv : Naukova dumka, V.2, 572. [in Ukrainian].

6. Fitzpatrick, P. (2002). The Mythology of Modern Law. London: Routledge. 256.
7. Gamkrelidze, T. V. \& Ivanov, V. V. (1995). Indo-European and the Indo-Europeans: A Reconstruction and Historical Analysis of a ProtoLanguage and Proto-Culture. Berlin - New York: Mouton de Gruyter, 1228.

8. Gukhman, M. M. (1981). Istoricheskaya tipologiya i problema diakhronicheskikh konstant [Historical typology and the problem of diachronic constants]. Moscow: Nauka publ., 249.

9. King Alfred Law Code. URL: http://www.dr-fnlee.org/docs6 /alfred/ alfred.pdf

10. Krasavskiy, N. A. (2000). Etimologicheskiy analiz sinonimicheskogo riada "strakh" (na materiale nemetskogo yazyka) [Etymological analysis of the synonymic row "Fear" (a German languagebased study). Kognitivnyye aspekty yazykovoy kategorizatsii: [sb. nauch. trudov] [Cognitive Aspects of Linguistic Categorization: Compendium of Scientific Works]. Riazan : RSPU Publ., 83-90. [in Russian].

11. Levitsksy, A (2016). Language worldview of Yakima Indians, compared with English and Ukrainians. Lege Artis. Language yesterday, today, tomorrow. The Journal of University of SS Cyril and Methodius in Trnava. Warsaw: De Gruyter Open, Vol. I (2), 80-128.

12. Melnychuk, N. Yu. (2006). Dyskurs zlochynu i pokarannia $\mathrm{v}$ konteksti klasychnoyi filosofskoyi paradyhmy [Discourse of "crime" and "punishment" in the context of classical philosophic paradigm]. Lviv: Lviv State University of Internal Affairs, 328. [in Ukrainian].

13. Online etymology dictionary. URL: http:// www. etymonline. com.

14. Rusk'a Pravda. Teksty na osnovi 5 redaktsiy. (1935). [Rusk'a Pravda. Texts based on 5 editions]. Yushkov, S. (comp. \& ed.). Kyiv: Academy of Science of Ukraine Publishers. URL: http://litopys.org.ua/yushkov/yu.htm/

15. Semehyn, T. (2011). Dynamika semantychnoyi struktury binarnykh kontseptiv PREKRASNYI/POTVORNYI $v$ anhliiskiy ta ukrayinskyi movakh [Semantic structure dynamics of binary concepts BEAUTIFUL/UGLY in English and Ukrainian]: Abstract of Thesis for a Candidate Degree in Philology. Speciality 10.02.17. Kyiv, 20. [in Ukrainian].

16. Staroslovianskiy slovar (po rukopisiam X-XI vekov). pod red. R. M. Tseitlin, R. Vecherki, E. Blagovoy (1999). [Old Slavic Dictionary (based on X-XI c. manuscripts). (eds.) R. Tseitlin, R. Vecherka, E. Blagova]. Moscow: Russkiy yazyk, 842. [in Russian].

17. Stepanov, Yu. (2007). Kontsepty: Tonkaya plenka tsivilizatsii [Concepts. A thin film of civilization]. Moscow: Languages of Slavonic Culture, 248. [in Russian]. 


\section{ДIАХРОНІЧНИЙ АНАЛІЗ КОНЦЕПТІВ CRIME I PUNISHMENT В. П. Сніцар}

Анотація. Статтю присвячено діахронному дослідженню концептів CRIME і PUNISHMENT, вербалізованих в англійській та українській мовах, поняттєво-змістове наповнення яких зазнало змін упродовж історичного розвитку. За допомогою етимологічного аналізу ключових лексемномінаторів цих концептів визначено їхню внутрішню форму. Встановлено, що первинними смисловими витоками концепту CRIME, закодованими у внутрішній фоормі його лексеминомінатора, є значення "cry" (крик), "to sift" (просіювати) в англійській мові, а в украӥнській мові для найменування злочину релевантною виявилася ознака несиметричності (кривий, похилий). Первісні уявлення про покарання у давньогерманській культурі пов'язувались із грошовим відшкодуванням та тілесним покаранням, а в праслов'янській - із тілесним покаранням і словесною образою.

У результаті реконструкції діахронного варіювання змісту концепту CRIME/ЗЛОчИН виявлено як спільні: 'порушення релігійно-моральних догм' (англ. sinfulness/ укр. гріх), так і відмінні концептуальні ознаки, актуалізовані в англійській мові: 'крик' (сry), 'відбір' (to sift, to discriminate) 'неправдивий вчинок' (deceit, fraud), 'обвинувачення' (charge, accusation), 'ненормативність' (crime, offence) та в українській мові: 'несиметричність' (кривий, похилий), 'моральні вади людини' (недобрий, злий), 'ціннісно-негативне явище' (нещастя, біда). Спільними в діахронному компоненті концепту PUNISHMENT/ПOКАРАННЯ є концептуальні ознаки: 'засіб впливу на порушника закону' (англ. punishment / укр. покарання), 'тілесне покарання' (англ. torment, suffering / укр. мучити, різати), а відмінними - 'грошове відшкодування' (penalty, compensation) та 'словесна образа' (сварити; різко, гостро ображати).

Розвиток способів вербалізації концептів CRIME/ЗЛОчИН і PUNISHMENT/ПOКАРАНHЯ у діахронії обумовлено набором когнітивно-дифреренційних ознак, які є комунікативно релевантними $i$ ціннісно значущими для сприйняття сутності злочину і покарання англосаксонським і українським етносом в межах певних історичних періодів.

Ключові слова: діахронне варіювання, діахронний компонент, концепт, лексема-номінатор, внутрішня форма, когнітивно-дифреренційна ознака. 